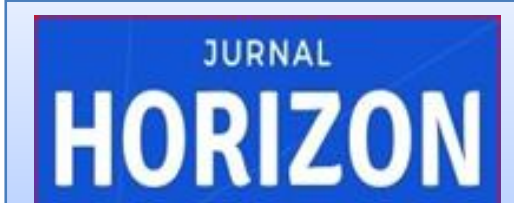

PENDIDIKAN
JURNAL HORIZON PENDIDIKAN

Publish by: Library of STKIP PGRI Sumatera Barat

E-ISSN : 2775-5770

Vol. 1 No. 4 (November 2021) (688-697)

http://ejournal.stkip-pgri-sumbar.ac.id/index.php/horizon

\title{
PENGARUH PENERAPAN PEMBELAJARAN KOOPERATIF TIPE PAIR \\ CHECKS TERHADAP HASIL BELAJAR MATEMATIKA SISWA KELAS VIII SMP PERTIWI 2 PADANG
}

Windi Maiendra, Hafizah Delyana, Lucky Heriyanti Jufri

Program Studi Pendidikan Matematika STKIP PGRI Sumatera Barat maihendrawindi@gmail.com

Submitted: 07-09-2021, Reviewed: 16-09-2021, Accepted: 10-11-2021

\begin{abstract}
The background of this research is that srudents' mathematics learning outcomes are still low, students participate less and have not maximized their role in group learning. The purpose of the study was to determine the improvement of students' mathematics learning outcomes by applying the pair checks type cooperative learning model to the VIII grade students of SMP Pertiwi 2 Padang. This type of research is descriptive research using quantitative methods with a one shoot case study research design. The population in this study were students of class VIII 1 SMP Pertiwi 2 Padang. The sampling technique was taken using purposive sampling, so that class VIII 1 SMP Pertiwi 2 Padang was chosen as the sample. The research instrument is a practice question for each meeting in the form of an essay with valid criteria. Based on the analysis of learning outcomes, it was found that the average student learning achievement in mathematics at the first meeting was 76 with students who scored more than the KKM (70) as many as 16 people, then decreased at the second meeting with an average learning outcome of 64 students who scored more than the KKM as many as 12 people, then it increased at the third meeting with an average learning outcome of 84 students who scored more than the KKM as many as 22 people. So it can be concluded that the increase in student learning outcomes fluctuated by applying the Pair Checks Cooperative learning model to class VIII 1 students of SMP Pertiwi 2 Padang.
\end{abstract}

\section{Keywords: Mathematics Learning, Pair Checks Type Cooperative Learning, Mathematics Learning Outcomes.}

\section{PENDAHULUAN}

Pendidikan merupakan cara untuk membentuk kemampuan manusia dalam menggunakan akal pikiran atau rasional mereka sebagai jawaban dalam menghadapi berbagai masalah. Melalui pendidikan yang baik kita akan mudah mengikuti perkembangan zaman. (Supriyanto, 2014). Ilmu pendidikan memiliki peran penting di dalam dunia pendidikan, matematika merupakan salah satu ilmu pendidikan yang telah banyak berkembang dewasa ini. 


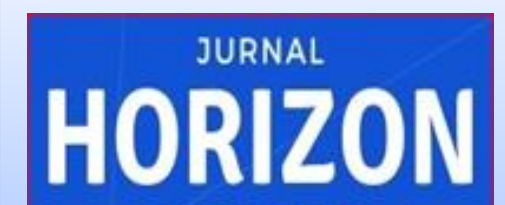

PENDIDIKAN

Publish by: Library of STKIP PGRI Sumatera Barat

E-ISSN : 2775-5770

Vol. 1 No. 4 (November 2021) (688-697)

http://ejournal.stkip-pgri-sumbar.ac.id/index.php/horizon

Matematika

berfungsi

mengembangkan

kemampuan

menghitung, mengukur, menemukan

dan menggunakan rumus matematika

yang dapat menunjang pemahaman

siswa terhadap pembelajaran

matematika. Menurut Nikson dalam

(Mulyardi, 2002: 3) "Pembelajaran

matematika adalah upaya untuk

membantu siswa mengkontruksikan

konsep-konsep atau prinsip-prinsip

matematika dengan kemampuan

sendiri melalui proses internalisasi

sehingga prinsip atau konsep itu

terbangun kembali”. Hal ini

menuntut siswa untuk belajar aktif,

keterlibatan siswa secara aktif

dipengaruhi oleh usaha guru dalam membelajarkan siswa.

Tujuan

pembelajaran

matematika itu sendiri adalah terbentuknya kemampuan bernalar pada diri siswa tercermin dalam kemampuan berpikir kritis, logis, sistematis, dan memiliki sifat objektif, jujur disiplin dalam memecahkan suatu permasalaha baik dalam bidang matematika, bidang lain maupun kehidupan sehari-hari (Persada, 2016).
Berdasarkan hasil observasi dan wawancara hasil belajar matematika siswa banyak berada di bawah KKM yaitu 70, siswa sibuk dengan pekerjaannya sendiri didalam kelompok belajar, kurangnya kemampuan siswa dalam berbagi informasi di dalam kelompok, saat proses pembelajaran guru telah membagi siswa secara berkelompok (4 sampai 5 orang), siswa tidak mau bertanya terhadap materi yang belum dipahami sedangkan saat diberi soal tentang materi yang telah dipelajari banyak siswa yang menjawab salah. Siswa tidak mau bertanya kepada guru karena tidak terbiasa, siswa terbiasa bertanya kepada temannya untuk meyakinkan bahwa jawaban latihan mereka benar.

Berdasarkan pernyataan di atas guru yang terlibat dalam proses pembelajaran dituntut dapat memilih model strategi pembelajaran yang tepat agar tujuan pembelajaran di sekolah dapat tercapai dengan baik. Penerapan model pembelajaran kooperatif dapat digunakan dalam pembelajaran matematika. Pembelajaran kooperatif akan meningkatkan partisipasi dan 


\section{Jupana HORIZON} PENDIDIKAN

JURNAL HORIZON PENDIDIKAN

Publish by: Library of STKIP PGRI Sumatera Barat

E-ISSN : 2775-5770

Vol. 1 No. 4 (November 2021) (688-697)

http://ejournal.stkip-pgri-sumbar.ac.id/index.php/horizon

kontribusi siswa dalam belajar kelompok karena siswa harus berbagi tugas dan berbagi tanggung jawab sama besarnya diantara para anggota kelompok. Menurut H. Karli dan Yuliartiningsih dalam (Istarani \& Ridwan, 2014) yaitu "Pembelajaran kooperatif adalah suatu strategi mengajar yang menekankan pada sikap atau perilaku bersama dalam bekerja atau membantu di antara sesama dalam struktur kerja sama yang teratur dalam kelompok, yang tersendiri atas dua dua orang atau lebih. Keberhasilan kerja sangat dipengaruhi keterlibatan setiap anggota kelompok itu sendiri”.

Pembelajaran Kooperatif Tipe Pair Checks merupakan alternatif yang baik untuk meningkatkan hasil belajar siswa. Pair Checks adalah sebuah model pembelajaran yang dapat melibatkan semua siswa pada proses pembelajaran. Dalam pembelajaran siswa dituntut untuk saling berbagi atau berkerjasama masing-masing kemampuan yang dimiliki siswa (Komara, 2010).

Pembelajaran Kooperatif Tipe Pair Checks merupakan kegiatan pengecekan berpasangan dan anggota kelompok yang terdiri dari dua orang siswa. Kegiatan pengecekan berpasangan menuntut siswa untuk lebih memahami materi pembelajaran karena sebagai pengecek siswa harus memahami materi pembelajaran dengan baik.

Menurut Slavin dalam (Hadi, s., \& Kasum, 2015) "Pembagian kelompok siswa secara berpasangan menunjukkan pencapaian yang jauh lebih besar dalam bidang ilmu pengetahuan dari pada kelompok yang terdiri atas empat atau lima orang". Untuk mengatasi hal tersebut dikembangkan suatu bentuk pendekatan dalam pembelajaran kooperatif tipe Pair Checks atau pengecekan berpasangan, dimana siswa terdiri dari dua orang dalam suatu kelompok kerja dan mengecek secara bergantian.

Berdasarkan uraian di atas, maka akan dilakukan penelitian dengan judul "Pengaruh Penerapan Model Pembelajaran Kooperatif Tipe Pair Checks terhadap Hasil Belajar Matematika Siswa Kelas VIII SMP Pertiwi 2 Padang".

\section{METODE PENELITIAN}




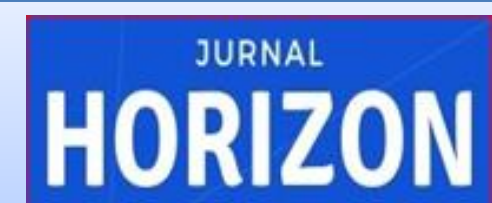

PENDIDIKAN

JURNAL HORIZON PENDIDIKAN

Publish by: Library of STKIP PGRI Sumatera Barat

E-ISSN : 2775-5770

Vol. 1 No. 4 (November 2021) (688-697)

http://ejournal.stkip-pgri-sumbar.ac.id/index.php/horizon

Penelitian dilaksanakan pada

Semester Genap di kelas VIII 1 dari tanggal 24 Februari sampai 2 Maret 2020 Tahun Pelajaran 2019/2020 kelas VIII SMP Pertiwi 2 Padang. Jenis penelitian ini adalah penelitian deskriptif dengan metode kuantitatif yang bertujuan untuk mengungkapkan suatu apa adanya pada saat penelitian dilakukan. Penelitian deskriptif tidak dimaksudkan untuk menguji hipotesis tertentu, tetapi hanya menggambarkan apa adanya tentang satu variable Penelitian kuantitatif banyak dituntut menggunakan angka, mulai dari mengumpulkan data penafsiran terhadap data tersebut serta penampilan dari hasilnya (Arikunto, 2006). Dapat disimpulkan bahwa penelitian deskriptif kuantitatif dalam penelitian ini adalah untuk melihat, meninjau dan menggambarkan dengan angka tentang objek yang diteliti seperti apa adanya dan menarik kesimpulan tentang hal tersebut sesuai dengan fenomena yang tampak pada saat penelitian dilakukan.

Definisi operasional variabel penelitian, variabel bebas dalam penelitian ini adalah pembelajaran matematika menggunakan model pembelajaran kooperatif tipe Pair Checks. Selanjutnya, variabel terikat adalah variabel yang diperkirakan akan dipengaruhi oleh variabel bebas maka yang menjadi variabel terikat adalah hasil belajar siswa kelas VIII SMP Pertiwi 2.

Populasi dalam penelitian adalah seluruh siswa kelas VIII 1 SMP Pertiwi 2 Padang tahun ajaran 2019/2020. Sedangkan pengambilan sampel dalam penelitian ini dilakukan dengan cara Purposive Sampling. Pengambilan sampel yang dilakukan adalah pengambilan kelas berdasarkan observasi yang dilakukan di awal Semester Ganjil di kelas VII, hasil belajar siswa dilihat dari nilai terbaru yaitu nilai ujian Semester Genap siswa kelas VII SMP Pertiwi 2 Padang tahun pelajaran 2018/2019 oleh sebab itu penelitian dapat dilakukan di kelas VIII 1. Ciri-ciri yang terdapat pada populasi pada saat observasi ditemukan pada kelas VII 1 yaitu hasil belajar matematika banyak berada di bawah KKM yaitu 70, siswa sibuk dengan pekerjaannya 
HORIZON

PENDIDIKAN
JURNAL HORIZON PENDIDIKAN

Publish by: Library of STKIP PGRI Sumatera Barat

E-ISSN : 2775-5770

Vol. 1 No. 4 (November 2021) (688-697)

http://ejournal.stkip-pgri-sumbar.ac.id/index.php/horizon sendiri di dalam kelompok belajar, kurangnya kemampuan siswa dalam berbagi informasi di dalam kelompok. Hasil wawancara dengan guru mengatakan bahwa hasil belajar siswa masih rendah, saat proses pembelajaran guru telah membagi siswa secara berkelompok (4 sampai 5 orang), siswa enggan bertanya terhadap materi yang belum dipahami sedangkan saat diberi soal tentang materi yang telah dipelajari banyak siswa yang menjawab salah. Hal ini sesuai dengan siswa yang mengatakan bahwa siswa enggan bertanya kepada guru karena tidak terbiasa, siswa terbiasa bertanya kepada temannya untuk meyakinkan bahwa jawaban latihan mereka benar.

Instrumen dari penelitian ini adalah soal latihan tiap pertemuan, soal latihan yang diberikan adalah soal latihan tertulis berupa soal-soal dalam bentuk uraian berdasarkan pokok bahasan.

Teknik pengumpulan data yaitu tahap persiapan, tahap pelaksanaan, dan tahap akhir. Menghitung skor penilaian hasil belajar matematika siswa diperlukan sebuah rubrik penilaian. Untuk mengukur hasil belajar matematika siswa pada penelitian ini, digunakan rubrik penilaian hasil belajar dengan skala 0-3.

Teknik analisis data hasil belajar siswa bertujuan untuk melihat ada atau tidak ada peningkatan hasil belajar matematika siswa.

\section{HASIL DAN PEMBAHASAN}

Data yang dimaksud dalam penelitian ini adalah hasil yang diperoleh dari soal latihan tiap pertemuan yang diberikan pada kelas eksperimen, yaitu kelas setelah menerapkan strategi pembelajaran Kooperatif tipe Pair Checks. Soal latihan hasil belajar pada kelas eksperimen diikuti 26 orang peserta didik. Soal latihan yang dilakukan pada pertemuan pertama berupa soal latihan essai dengan 3 butir soal, pertemuan kedua berupa soal latihan essai dengan 4 butir soal, dan pertemuan ketiga berupa soal latihan essai dengan 4 butir soal.

Skor hasil belajar siswa dapat ditentukan dengan perhitungan ratarata $(\bar{X})$, simpangan baku $(S)$, skor 


\section{Jupach HORIZON} PENDIDIKAN
JURNAL HORIZON PENDIDIKAN

Publish by: Library of STKIP PGRI Sumatera Barat

E-ISSN : 2775-5770

Vol. 1 No. 4 (November 2021) (688-697)

http://ejournal.stkip-pgri-sumbar.ac.id/index.php/horizon tertinggi $\left(X_{\text {maks }}\right)$ dan skor terendah $\left(X_{\min }\right)$.

Tabel.1 Hasil Perhitungan Nilai Latihan Siswa

\begin{tabular}{cccccc}
\hline Kelas & $\overline{\boldsymbol{X}}$ & $\boldsymbol{S}$ & $\boldsymbol{X}_{\operatorname{maks}} \boldsymbol{X}_{\min }$ \\
Sampel & & & & \\
Pertemuan 1 & 76 & 27.09 & 100 & 33 \\
Pertemuan 2 & 64 & 25.25 & 100 & 17 \\
Pertemuan 3 & 84 & 21.19 & 100 & 24 \\
\hline
\end{tabular}

Berdasarkan Tabel.1 dapat

dilihat bahwa nilai rata-rata latihan siswa pertemuan pertama adalah 76 dan simpangan baku sebesar 27.09. Ini berarti sebaran data mendekati nilai rata-rata hasil belajar skor siswa dengan skor tertinggi 100 dan skor terendah 33. Pada pertemuan kedua nilai rata-rata latihan siswa adalah 64 dan simpangan baku sebesar 25.25. Ini berarti sebaran data mendekati nilai rata-rata hasil belajar dengan skor tertinggi 100 dan skor terendah 17. Nilai rata-rata latihan siswa pada pertemuan ketiga yaitu 84 dan simpangan baku sebesar 21.19. Ini berarti sebaran data mendekati nilai rata-rata hasil belajar dengan skor tertinggi 100 dan skor terendah 24

Analisis data memiliki tujuan untuk menjawab pertanyaan penelitian yaitu bagaimana hasil belajar matematika siswa dengan menerapkan model pembelajaran Kooperatif tipe Pair Checks pada siswa kelas VIII SMP Pertiwi 2 Padang

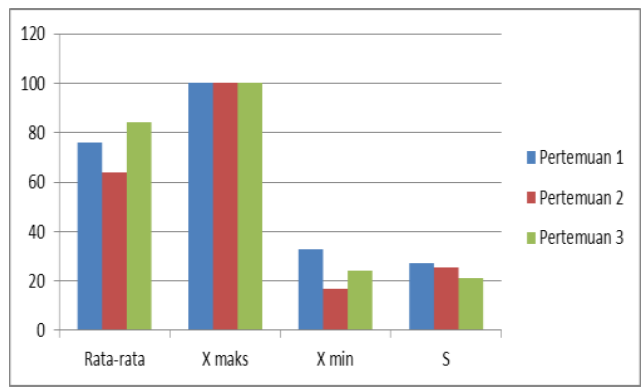

Gambar 1. Histogram hasil belajar siswa.

Berdasarkan gambar 2. Histogram hasil belajar siswa dapat dilihat bahwa rata-rata hasil belajar siswa pada pertemuan pertama adalah 76 , kemudian rata-rata hasil belajar siswa mengalami penurunan pada pertemuan kedua yaitu 64, selanjutnya rata-rata hasil belajar siswa mengalami peningkatan pada pertemuan ketiga dengan nilai 84 . Jadi dapat disimpulkan bahwa hasil belajar matematika siswa mengalami peningkatan dengan menerapkan model pembelajaran Kooperatif tipe Pair Checks pada siswa kelas VIII SMP Pertiwi 2 padang.

Tahap pelaksanaan, fase pertama pada model pembelajaran Kooperatif tipe Pair Checks adalah pendidik 
HORIZON

PENDIDIKAN
JURNAL HORIZON PENDIDIKAN

Publish by: Library of STKIP PGRI Sumatera Barat

E-ISSN : 2775-5770

Vol. 1 No. 4 (November 2021) (688-697)

http://ejournal.stkip-pgri-sumbar.ac.id/index.php/horizon menyampaikan tujuan pembelajaran

1. Mencermati model atau benda di sekitar yang mempresentasikan bangun ruang sisi datar 2. Melakukan percobaan untuk menemukan jaringjaring bangun ruang sisi datar. Fase kedua menyajikan informasi, pendidik memberi ilustrasi masalah berupa gambar kotak roti, kotak kue, atap gubuk, tenda, atap rumah dan jaring-jaring bangun ruang sisi datar yang terdapat didalam buku ajar. Fase ketiga pendidik membagi siswa dengan membentuk tim secara berpasangan dan membagikan lembar jawaban siswa beserta kupon yang telah disematkan pada lembar jawaban kepada masing-masing siswa. Fase ke empat pendidik mengarahkan peserta didik untuk berdiskusi dalam kelompok tentang materi jaring-jaring kubus, balok, prisma, dan limas. Fase kelima evaluasi 1. Bekerja berpasangan, pendidik menginstruksi siswa mengerjakan soal latihan 2. Siswa yang berperan sebagai pelatih mencek hasil kerja partner jika partner benar pelatih memberi kupon 3. Seluruh pasangan tim saling bertukar peran, pertukaran peran terus dilakukan setiap satu buah soal latihan telah diselesaikan.

Pertemuan pertama, siswa telah mampu menjawab soal latihan tentang materi jaring-jaring bangun ruang sisi datar. Pada pertemuan pertama ini sebagian besar siswa menjawab soal latihan dengan benar.

Pertemuan kedua, ada siswa yang tidak mampu menjawab soal latihan tentang materi luas permukaan dan volume bangun ruang sisi datar dengan benar, sebagian besar siswa belum dapat menjawab soal latihan dengan benar. Pada pertemuan kedua siswa sudah terbiasa dengan langkah-langkah pembelajaran Kooperatif tipe Pair Checks namun belum dapat menjawab soal latihan dengan benar.

Pertemuan ketiga, siswa telah mampu menjawab soal latihan tentang materi kubus, balok, prisma dan limas. Pada pertemuan ketiga ini sebagian besar siswa menjawab soal latihan dengan benar. Pelaksanaan pembelajaran Kooperatif tipe Pair Checks semakin membaik. Siswa sudah terbiasa dengan pasangannya dan tidak ada lagi permintaan untuk mengganti pasangannya pada tiap 
HORIZON

PENDIDIKAN
JURNAL HORIZON PENDIDIKAN

Publish by: Library of STKIP PGRI Sumatera Barat

E-ISSN : 2775-5770

Vol. 1 No. 4 (November 2021) (688-697)

http://ejournal.stkip-pgri-sumbar.ac.id/index.php/horizon kelompok kepada pendidik. Siswa tampak serius dalam memahami materi.

Soal latihan, latihan dilakukan dalam tiga tahap yaitu latihan pertemuan pertama pada tanggal 24 Februari 2020 dengan soal berupa essai sebanyak 3 butir soal, latihan pertemuan kedua pada tanggal 25 Februari 2020 berupa essai sebanyak 4 butir soal, dan latihan pertemuan ketiga pada tanggal 2 Maret 2020 berupa essai sebanyak 4 butir soal di kelas VIII 1 yang terdiri dari 26 siswa

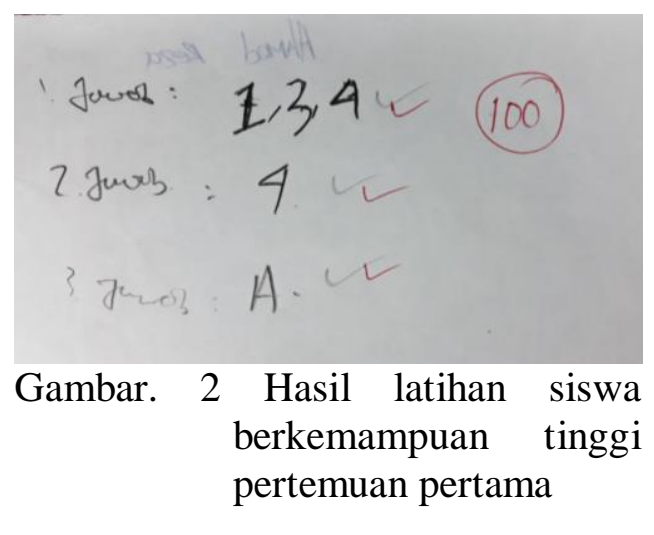

Gambar 2 dapat dilihat bahwa siswa berkemampuan tinggi sudah bisa menjawab semua pertanyaan dengan materi pembelajaran jaring-jaring bangun ruang sisi datar, siswa dapat menyebutkan jaring-jaring yang sesuai dengan bangun ruang sisi datar dan bisa menentukan bagian dari jaring-jaring jika bagian jaring-jaring yang lainnya diketahui sesuai pertanyaan soal latihan dengan tepat dan benar.

Pada pertemuan pertama ini, siswa yang memperoleh nilai lebih dari KKM (70) ada sebanyak 16 orang sedangkan 10 siswa lainnya belum dapat mencapai nilai sama atau lebih dari KKM.

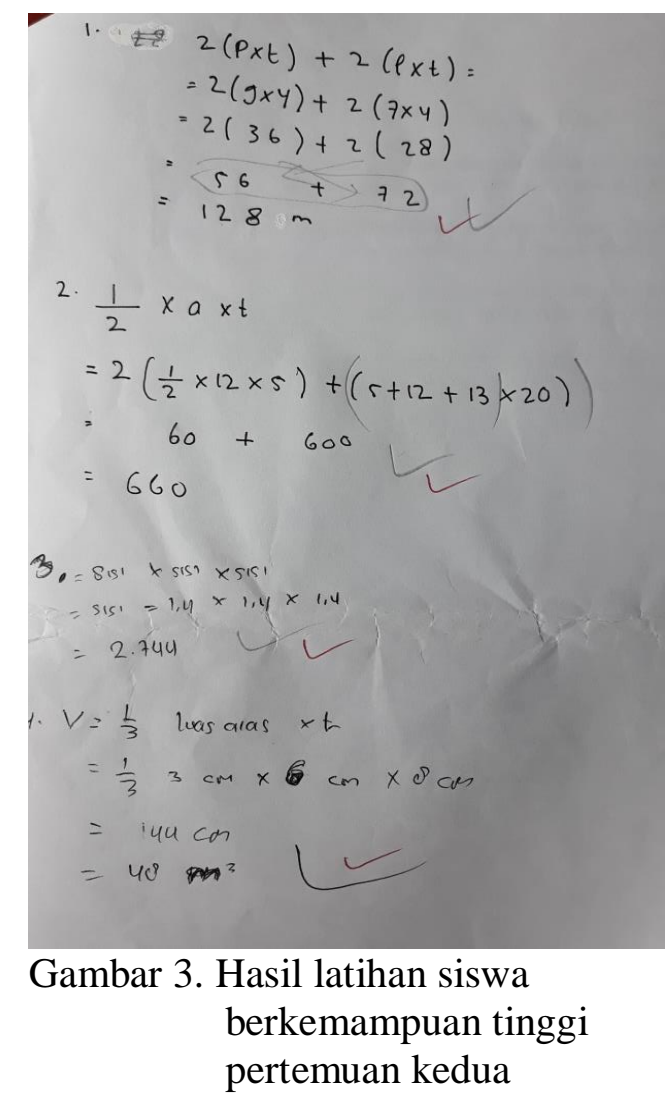

Gambar 3 dapat dilihat Siswa berkemampuan tinggi dapat menjawab semua pertanyaan secara benar dengan materi pembelajaran luas permukaan dan volume bangun ruang sisi datar. Semua jawaban dan perhitungan yang dilakukan siswa benar, siswa tidak 
HORIZON

PENDIDIKAN
JURNAL HORIZON PENDIDIKAN

Publish by: Library of STKIP PGRI Sumatera Barat

E-ISSN : 2775-5770

Vol. 1 No. 4 (November 2021) (688-697)

http://ejournal.stkip-pgri-sumbar.ac.id/index.php/horizon mengalami kesulitan dalam menjawab pertanyaan.

Pada pertemuan kedua ini, banyak siswa yang memperoleh nilai sama atau lebih dari KKM (70) mengalami penurunan yaitu sebanyak 12 siswa dengan rata-rata nilai 64. Hal ini mengalami penurunan jika dibandingkan dengan dengan hasil belajar siswa pada pertemuan pertama yang memperoleh nilai yang sama atau lebih dari KKM sebanyak 16 orang dengan rata-rata nilai 76 .

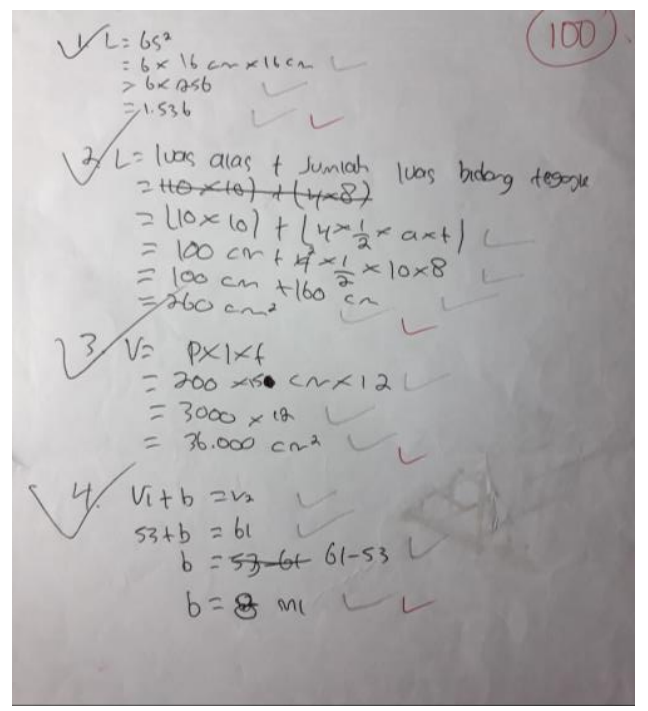

Gambar 4. Hasil latihan siswa berkemampuan tinggi pertemuan ketiga

Gambar 4 dapat dilihat bahwa siswa berkemampuan tinggi dapat menjawab semua pertanyaan tentang materi pembelajaran kubus, balok, prisma dan limas dengan benar. Siswa dapat menggunakan rumus dengan tepat sesuai dengan perintah soal, pada perhitungan matematis siswa dapat menyelesaikan dengan baik sehingga semua jawaban yang diperoleh siswa benar. Tidak ada kesulitan yang berarti dialami oleh siswa.

Pada pertemuan ketiga ini, banyak siswa yang memperoleh nilai sama atau lebih dari KKM (70) mengalami peningkatan yaitu ada sebanyak 22 orang dengan rata-rata hasil belajar 84 .

\section{KESIMPULAN}

Berdasarkan hasil analisis data dan pembahasan yang telah dikemukakan diperoleh bahwa ratarata hasil belajar matematika siswa pada pertemuan pertama adalah 76 dengan siswa yang memperoleh nilai lebih dari KKM (70) sebanyak 16 orang, kemudian mengalami penurunan pada pertemuan kedua dengan rata-rata hasil belajar 64 siswa yang memperoleh nilai lebih dari KKM sebanyak 12 orang, selanjutnya mengalami peningkatan pada pertemuan ketiga dengan ratarata hasil belajar 84 siswa yang memperoleh nilai lebih dari KKM sebanyak 22 orang. Jadi dapat disimpulkan bahwa peningkatan 


\section{Jubat HORIZON} PENDIDIKAN
JURNAL HORIZON PENDIDIKAN

Publish by: Library of STKIP PGRI Sumatera Barat

E-ISSN : 2775-5770

Vol. 1 No. 4 (November 2021) (688-697)

http://ejournal.stkip-pgri-sumbar.ac.id/index.php/horizon hasil belajar siswa mengalami

fluktuatif dengan menerapkan model

pembelajaran Kooperatif tipe Pair

Checks pada siswa kelas VIII SMP

Pertiwi 2 Padang.

\section{DAFTAR PUSTAKA}

Arikunto, S. (2010). Prosedur Penelitian Suatu Pendekatan Praktik. Rineka Cipta.

Depdiknas. (2001). Menyusun Butir Soal dan Instrumen Penilaian. Dikdasmen.

Hadi, s., \& Kasum, M. U. (2015). Pemahaman Konsep Siswa Melalui Penerapan Model Pembelajaran Kooperatif Tipe Memeriksa Berpasangan (Pair Checks). 3, 59-66.

Istarani \& Ridwan, M. (2014). Tipe Pembelajaran Kooperatif. CV. Media Persada.

Komara, S. (2010). Pengaruh Model Pembelajaran Kooperatif Tipe Par Checks Terhadap Hasil
Belajar Matematika Siswa (Kuasi Eksperimen)di MTs Negeri 22 Jakarta Timur.

Mulyardi. (2002). Strategi Pembelajaran Matematika. Universitas Negeri Padang.

Persada, A. R. (2016). Pengaruh Model Pembelajaran Penemuan (Discovery Learning) Terhadap Kemampuan Koneksi Matematika Siswa (Studi Eksperimen) Terhadap Siswa Kelas VII SMPN 2 Sindangagung Kabupaten Kuningan Pada Pokok Bahasan Segiempat.

Supriyanto, B. (2014). Penerapan Discovery Learning Untuk Meningkatkan Hasil Belajar Siswa Kelas VI B Mata Pelajaran Matematika Pokok Pembahasan Keliling dan Luas Lingkaran di SDN Tanggul Wetan 02 Kecamatan Tanggul Kabupaten Jember. 